NASA/TM-2004-213225

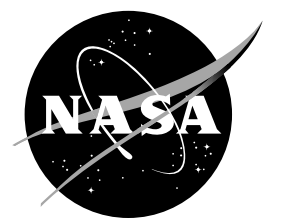

Nuclear Electric Propulsion Application: RASC Mission Robotic Exploration of Venus

Melissa L. McGuire and Stanley K. Borowski

Glenn Research Center, Cleveland, Ohio

Thomas W. Packard

Analex Corporation, Brook Park, Ohio 
Since its founding, NASA has been dedicated to the advancement of aeronautics and space science. The NASA Scientific and Technical Information (STI) Program Office plays a key part in helping NASA maintain this important role.

The NASA STI Program Office is operated by Langley Research Center, the Lead Center for NASA's scientific and technical information. The NASA STI Program Office provides access to the NASA STI Database, the largest collection of aeronautical and space science STI in the world. The Program Office is also NASA's institutional mechanism for disseminating the results of its research and development activities. These results are published by NASA in the NASA STI Report Series, which includes the following report types:

- $\quad$ TECHNICAL PUBLICATION. Reports of completed research or a major significant phase of research that present the results of NASA programs and include extensive data or theoretical analysis. Includes compilations of significant scientific and technical data and information deemed to be of continuing reference value. NASA's counterpart of peerreviewed formal professional papers but has less stringent limitations on manuscript length and extent of graphic presentations.

- TECHNICAL MEMORANDUM. Scientific and technical findings that are preliminary or of specialized interest, e.g., quick release reports, working papers, and bibliographies that contain minimal annotation. Does not contain extensive analysis.

- CONTRACTOR REPORT. Scientific and technical findings by NASA-sponsored contractors and grantees.
- CONFERENCE PUBLICATION. Collected papers from scientific and technical conferences, symposia, seminars, or other meetings sponsored or cosponsored by NASA.

- SPECIAL PUBLICATION. Scientific, technical, or historical information from NASA programs, projects, and missions, often concerned with subjects having substantial public interest.

- TECHNICAL TRANSLATION. Englishlanguage translations of foreign scientific and technical material pertinent to NASA's mission.

Specialized services that complement the STI Program Office's diverse offerings include creating custom thesauri, building customized databases, organizing and publishing research results ... even providing videos.

For more information about the NASA STI Program Office, see the following:

- Access the NASA STI Program Home Page at http://www.sti.nasa.gov

- E-mail your question via the Internet to help@sti.nasa.gov

- Fax your question to the NASA Access Help Desk at 301-621-0134

- Telephone the NASA Access Help Desk at 301-621-0390

- Write to:

NASA Access Help Desk

NASA Center for AeroSpace Information 7121 Standard Drive

Hanover, MD 21076 
NASA/TM-2004-213225

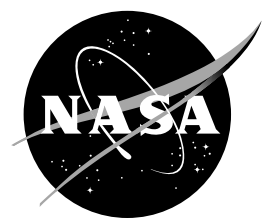

\section{Nuclear Electric Propulsion Application: RASC Mission Robotic Exploration of Venus}

Melissa L. McGuire and Stanley K. Borowski

Glenn Research Center, Cleveland, Ohio

Thomas W. Packard

Analex Corporation, Brook Park, Ohio

Prepared for the

40th Joint Propulsion Conference and Exhibit

cosponsored by the AIAA, ASME, SAE, and ASEE

Fort Lauderdale, Florida, July 11-14, 2004

National Aeronautics and

Space Administration

Glenn Research Center 


\section{Acknowledgments}

M.L. McGuire would like to thank the members of the Systems Analysis Branch and the Systems Engineering Division of the NASA Glenn Research Center for their continued support throughout this study. Further recognition is given to Geoffrey Landis for providing direction and encouragement as the Principle Scientific Investigator for this mission study.

Available from

NASA Center for Aerospace Information 7121 Standard Drive

Hanover, MD 21076
National Technical Information Service 5285 Port Royal Road Springfield, VA 22100

Available electronically at http:/ /gltrs.grc.nasa.gov 


\title{
Nuclear Electric Propulsion Application: RASC Mission Robotic Exploration of Venus
}

\author{
Melissa L. McGuire and Stanley K. Borowski \\ National Aeronautics and Space Administration \\ Glenn Research Center \\ Cleveland, Ohio 44135 \\ Thomas W. Packard \\ Analex Corporation \\ Brook Park, Ohio 44142
}

The following paper documents the mission and systems analysis portion of a study in which Nuclear Electric Propulsion (NEP) is used as the in-space transportation system to send a series of robotic rovers and atmospheric science airplanes to Venus in the 2020 to 2030 timeframe. As part of the NASA RASC (Revolutionary Aerospace Systems Concepts) program, this mission analysis is meant to identify future technologies and their application to far reaching NASA missions. The NEP systems and mission analysis is based largely on current technology state of the art assumptions. This study looks specifically at the performance of the NEP transfer stage when sending a series of different payload package point design options to Venus orbit.

\section{Nomenclature}

RASC Revolutionary Aerospace Systems Concept

NEP Nuclear Electric Propulsion

PPU Power Processing Unit

ELV Expendable Launch Vehicle

LEO Low Earth Orbit

MER Mass Estimating Relationship

IMLEO Initial Mass in Low Earth Orbit

SRPS Space Reactor Power System

Isp Specific Impulse (sec)

HEDS Human Exploration and Development of Space

DRM Design Reference Mission

\section{Background of the RASC Program}

The Revolutionary Aerospace Systems Concept (RASC) program is meant to study alternative approaches to achieving NASA's missions that may occur beyond traditional planning horizons. The focus of this activity is on missions that would occur between 2015 and 2030. These studies are meant to leverage NASA expertise across the agency to identify key technological developments needed to perform farther-reaching exploration beyond the current scheduled NASA missions. Further details can be found at the RASC website (reference 1). 


\section{Background of Venus Robotic Probe Mission}

Envisioned as a science driven, technology enabled mission, the Robotic Exploration of Venus mission aims to fill in some of the missing pieces in the quest to understand the nature of the planet Venus. The Venus Robotic Exploration Mission scientific research concept is to cover the surface and atmosphere of Venus with several rovers and airplanes, respectively. Per the RASC guidelines, this mission's timeframe includes a launch in 2020 or later. All trajectories run for the specific 2020 opportunity are representative of the worst case of the opportunities in the decade between 2020 and 2030.

\section{Why Use NEP?}

NASA has a long history of studying the use of Nuclear Electric Propulsion (NEP) as the primary propulsion system for a planetary spacecraft. (reference 2) The use of NEP, to perform the in-space transfer of a payload for the RASC Venus Robotic mission is a logical study candidate. NEP has the capability of sending heavier payloads, although at the cost of trip time, with much less initial mass at Earth than many other propulsion technologies. Using NEP in this mission allows for more probes to be delivered to Venus than could be delivered using traditional Chemical propulsion systems.

\section{Venus Payload Description}

The initial intent of the mission to Venus is to deploy a series of both robotic rovers as well as airplanes about the surface and in the atmosphere of Venus. These robotic vehicles will be able to collect far more detailed data than anything done to this date on Venus. The NEP mission analysis is performed by concentrating on point designs with known payload masses based on numbers given below.

\section{A. Initial Payload Packaging Options}

The Venus exploration baseline mission plan includes 4 rovers, 4 rover-control airplanes, and 4 atmospheric sampling airplanes (plus other probes associated with these: atmospheric probes, seismometers). Each set, which consists of rover/rover-controlled airplane and atmospheric airplane plus aeroshell, attachment truss and associated contingency, is referred to as a package. Each package item has a 30\% contingency. Individual aeroshells, one about each package, uses a $27 \%$ mass factor. Communications package assumed at $100 \mathrm{~kg}$ for each payload package.

\section{B. Payload Down-Select Options}

After the launch vehicle payload fairing packaging and redesign phases of the study, the final payload volume has to be downsized/reduced. In order to provide a series of mission choices, the following six payload options are scoped out and are listed in order of "best" to "worst" in terms of the science return expectations of the Venus mission Principle Investigator.

\begin{tabular}{|c|c|c|c|c|c|c|}
\hline Option & Items (payload manifest) & $\begin{array}{l}\text { Mass } \\
\text { Rovers }\end{array}$ & $\begin{array}{c}\text { Mass } \\
\text { Airplanes }\end{array}$ & Total Mass & $\begin{array}{c}\text { Mass with } \\
\text { Central } \\
\text { Truss }\end{array}$ & \\
\hline 1 & $\begin{array}{c}4 \text { rovers, } 4 \text { rover-control } \\
\text { airplanes, } 2 \text { atmospheric } \\
\text { sampling airplanes }\end{array}$ & 3448 & 4952 & 8400 & 9240 & $\mathrm{~kg}$ \\
\hline 2 & $\begin{array}{c}3 \text { rovers, } 3 \text { rover-control } \\
\text { airplanes, } 2 \text { atmospheric } \\
\text { sampling airplanes }\end{array}$ & 2586 & 4127 & 6713 & 7384 & $\mathrm{~kg}$ \\
\hline 3 & $\begin{array}{c}3 \text { rovers, } 3 \text { rover-control } \\
\text { airplanes, } 1 \text { atmospheric } \\
\text { sampling airplanes }\end{array}$ & 2586 & 3301 & 5887 & 6476 & $\mathrm{~kg}$ \\
\hline 4 & $\begin{array}{c}2 \text { rovers, } 2 \text { rover-control } \\
\text { airplanes, } 1 \text { atmospheric } \\
\text { sampling airplanes }\end{array}$ & 1724 & 2476 & 4200 & 4620 & $\mathrm{~kg}$ \\
\hline 5 & $\begin{array}{c}2 \text { rovers, } 2 \text { rover-control } \\
\text { airplanes, no atmospheric } \\
\text { sampling airplanes }\end{array}$ & 1724 & 1651 & 3375 & 3712 & $\mathrm{~kg}$ \\
\hline 6 & 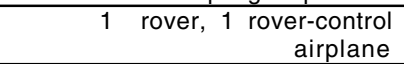 & 862 & 825 & 1687 & 1856 & $\mathrm{~kg}$ \\
\hline
\end{tabular}

Figure 1.- Venus science payload down-select options. 
All six options will work based on just the given payload configuration. However, when the prescribed volumetric constraints of the Expendable Launch Vehicle (ELV) fairing, the mass performance capabilities of the Delta IV H to LEO, and the capabilities of the NEP transfer stage to Venus orbit are factored in, only options 3 and 4 are feasible. Trajectory analysis point design details in this paper are only presented for option 4.

\section{NEP Stage System description}

Technology assumptions for the NEP vehicle are appropriate for a mission to be launched in the 2020 to 2030 timeframe. Most numbers are derived from current best estimates for NEP transfer stage component technology masses in the specified timeframe for launch.

\section{Power and Propulsion System}

Six HIPEP model ion thrusters are used as the EP thruster system for the NEP stage. The propulsion system consists of four active thrusters with each one operating at $25 \mathrm{kWe}$ individual thruster masses of $30 \mathrm{~kg}$ each and two spares. Each thruster has its own Power Processing Unit (PPU) with a mass of $100 \mathrm{~kg}$. Thruster efficiency is assumed at $75 \%$ for this power level. Per the HIPEP research, the thruster Isp operating levels range from 4000 to 6100 seconds. The trajectory analysis concentrated on the point designs at either end of the allowable Isp range. The point design reported in this paper is for the $6100 \mathrm{sec}$ case. The propellant tank is modeled using a tankage fraction of $16 \%$. This percentage is based on previous analytical calculations of tanks done for HEDS DRM 4.0 studies and the RASC

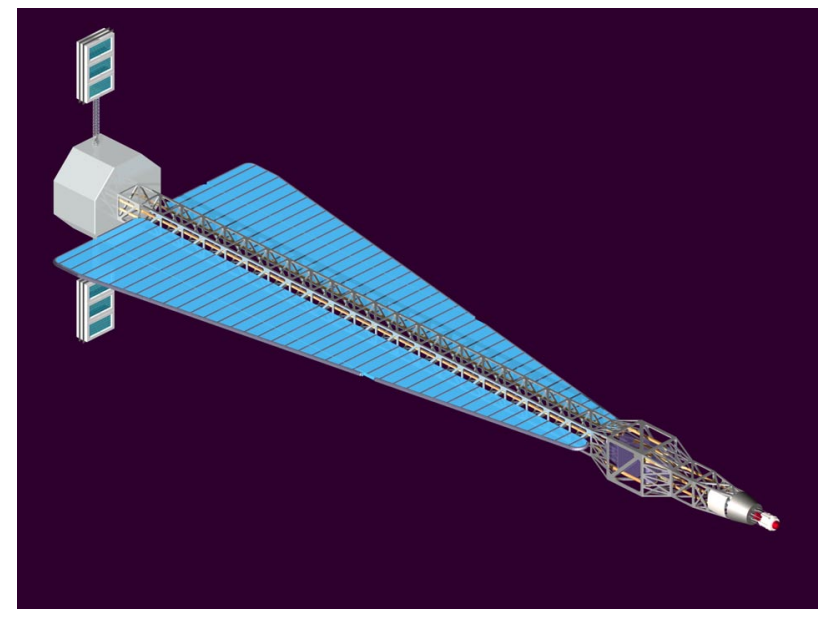

Figure 2.-NEP transfer stage showing thrusters, radiator and Brayton Reactor. HOPE mission (reference 6). The assumptions of past mass estimating relationships (MERs) include MLI of 1.5-inch thickness, ullage, or unfilled airspace in the tanks of $2.5 \%$, micrometeoroid shielding and launch loads of 3 to $6 \mathrm{gs}$.

A liquid metal Brayton Cycle reactor provides power to the thrusters and the science instruments on the transfer stage. The dry mass of the NEP stage is $9096 \mathrm{~kg}$. This mass included the Reactor and power conversion system $(6273 \mathrm{~kg})$, tank structure, attitude control system, communications, Reaction Control system (RCS), thruster cabling, PPU, and Ion thruster mass. A 24 to $30 \%$ contingency factor is applied to individual vehicle system components to arrive at the contingency dry mass of the vehicle. The tank mass is dependant on propellant load and is therefore not included in the dry mass estimate.

\section{Low Thrust Mission and Systems Analysis}

\section{Low Thrust Trajectory Tool Description: VARITOP}

The low thrust mission analysis simulation program VARITOP is used to determine the optimal trajectories in each case. VARITOP is designed to optimize interplanetary low-thrust trajectories where the ratio of thrust acceleration to local gravity is high enough to preclude the use of perturbative techniques but low enough that trajectory arcs cannot be approximated using impulsive burns. This program is similar in concept to an impulsive ballistic patched conic program where the planets are assumed massless in calculating the interplanetary transfer trajectory. Planetary positions and velocities are computed from stored analytic conic elements of the nine major planets. Conic elements are available for both numbered and unnumbered asteroids and for short period comets (reference 3 ). 


\section{E. Trajectory Analysis Assumptions}

The NEP stage is initially inserted into a $500 \mathrm{~km}$ circular orbit by a Delta IV H ELV. Two launches are necessary to deliver the NEP stage and the payload packages. Volume limitations of the Delta IV H payload fairing prevent the NEP stage and the payload package from fitting in one launch. Autonomous rendezvous and docking is assumed in LEO of the NEP stage and the payload. The NEP transfer vehicle spiral-escapes from the $500 \mathrm{~km}$ circular orbit, and spiral captures into a Venus orbit with a 2-hour period. Assuming a circular orbit, a two hour orbit period required a Venus altitude of $1475 \mathrm{~km}$.

In order to find the optimal departure dates for the low thrust trajectory, a series of impulsive trajectory cases are run with the patched conic trajectory tool MIDAS (reference 4 and 5). These trajectories show a sensitivity to departure date when used to arrive at a converged, minimum energy case. Figure 3 shows an eightyear cycle between lowest energy (and therefore minimum time) opportunities. The chosen 2020 departure opportunity represents a maximum energy impulsive case with a $\mathrm{C} 3$ of $21 \mathrm{~km}^{2} / \mathrm{sec}^{2}$. By contrast, the 2015 opportunity has a ballistic trajectory $\mathrm{C} 3$ of $7.5 \mathrm{~km}^{2} / \mathrm{sec}^{2}$ and is the minimum energy for this cycle.

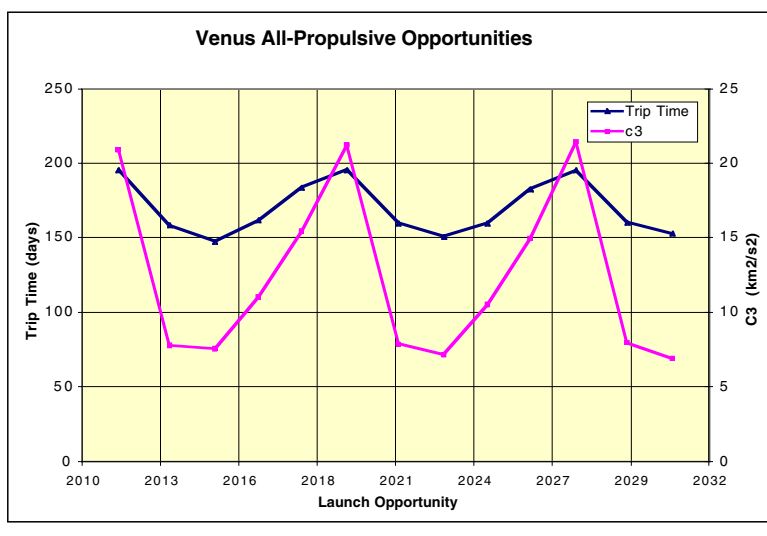

Figure 3.-Ballistic Venus opportunity cycle.

\section{F. Range of Payloads}

In order to assess the impact on IMLEO and trip time of the NEP system, trajectory point designs for the first four payload options in the Venus down-select payload option tradespace were analyzed. The trend in Figure 4 shows that all payload options have a mass margin available in the Delta IV H NEP stage launch. The available mass margin in the NEP stage launch can be used for extra propellant. Payload volume packaging analysis of the aeroshells and support structure eliminates all but options 3 and 4 from the available trade space.

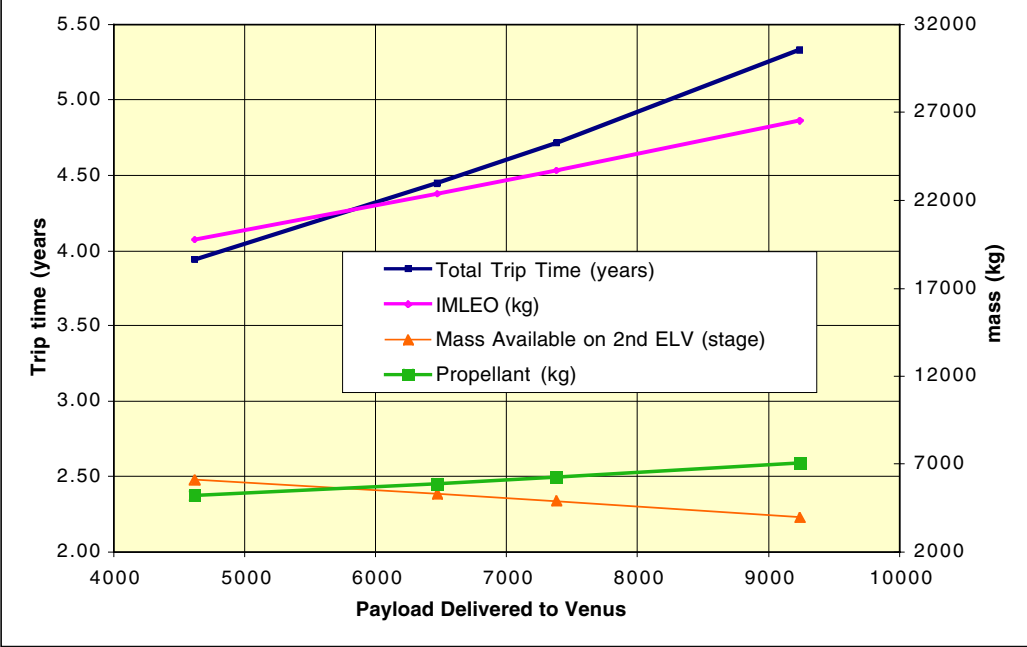

Figure 4.- Trip time and mass as a function of payload delivered to Venus.

\section{G. 2020 Opportunity: Representative Trajectory Point Design}

Payload option number 4 is the most realistic one in terms of volume required by the payload package in the ELV fairing. This option contains two rovers, each controlling an airplane, and one atmospheric science airplane. The low thrust trajectory analysis assumed payload delivered mass for the 2 rovers and 3 airplanes of $4620 \mathrm{~kg}$. Using the NEP dry mass of $9096 \mathrm{~kg}$, tank mass of $842 \mathrm{~kg}$, and the payload from 
option 4, the IMLEO estimation of the NEP vehicle is $19758 \mathrm{~kg}$. Since the Delta IV H is capable of injecting $21000 \mathrm{~kg}$ to this LEO, there is mass margin available on the dual launch configuration. Departing on 3/6/2018 from LEO of $500 \mathrm{~km}$, the NEP stage spends 561 days in spiral departure of the earth. After 472 days in heliocentric space, the NEP vehicle arrives at Venus 1/3/2021. Spiral capturing for 404 days, the Venus payload is in a two-hour period Venus orbit on 2/11/2022. Using an Isp of 6100 seconds and HIPEP efficiency assumptions, the propellant budget is $5200 \mathrm{~kg}$. Figure 5 depicts the heliocentric leg from Earth to Venus of the 2020 mission opportunity.

\section{Issues and Conclusions}

The use of NEP as the transportation stage for the Venus mission enables a large amount of payload to be transported. The cost associated with this high performance is a lengthy trip time mission. Including the spiral portions at Earth and Venus, the total transfer times for the four payload options range from 3.9 years to 5.3 years. Operating at higher power levels (than $100 \mathrm{kWe}$ ) or at lower Isp (than $6100 \mathrm{sec}$ ) may improve trip times but at the cost of power system mass or propellant.

If the longer trip times are accepted, the mass margin remaining on the ELV launch of the NEP transfer stage can be used for return propellant. This return propellant will enable sample return missions from Venus. Due to the limits of the launch vehicle and the size of the reactor radiator, the NEP system is volume-limited and not masslimited, in performing the Venus mission. With

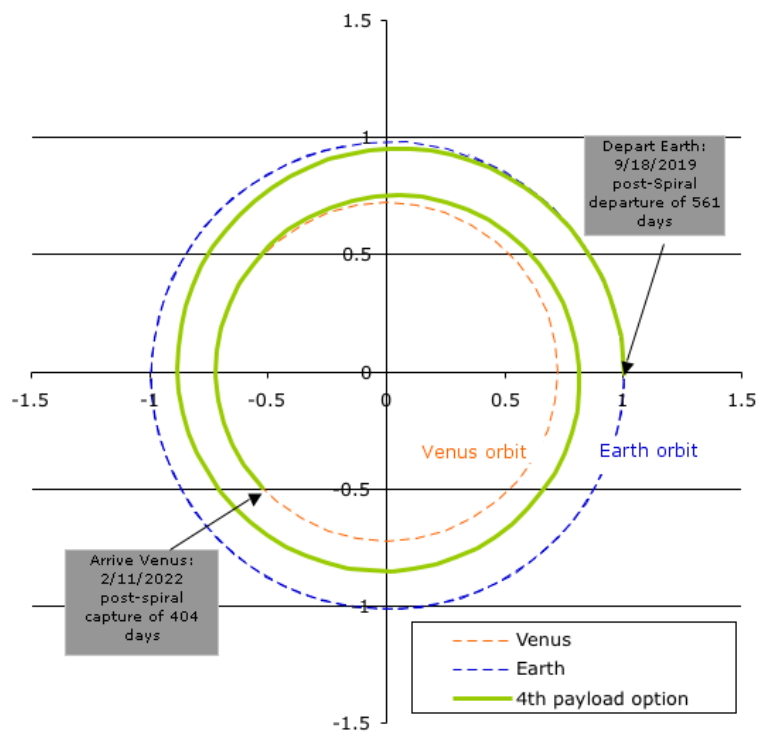

Figure 5.-Representative trajectory of $\mathbf{2 0 2 0}$ opportunity payload option 4.

the excess mass margin available on the launch vehicle, it is possible to add in additional propellant or additional payload mass to extend the mission capabilities of the NEP stage.

\section{Future Work}

In order to lower the trip times to Venus, two trades-offs should be examined in the NEP power and propulsion system. Operating the reactor at higher power levels will improve the thrust to weight ratio of the NEP system; the impacts on the trajectory should be investigated. A second trade study for this mission should concentrate on the application of Hall thrusters at lower Isps. The lower Isp, while costing more in propellant, should reduce the trip times. The mass margin, available on the Delta IV $\mathrm{H}$ in this analysis, could provide additional propellant.

Next steps to the mission analysis for this Venus mission include alternate EP systems for power and propulsion. A logical option, given the proximity to the sun, would be to use an SEP system as the primary propulsion and power system. This analysis looks only at the NEP option, but future analyses should also look at the capabilities of an SEP transfer stage to perform this Venus mission.

\section{References}

1. RASC main web site http://rasc.larc.nasa.gov/rasc_new/index.html

2. Project Prometheus main web page: http://spacescience.nasa.gov/missions/prometheus.htm, July 2004.

3. VARITOP description from branch (7820) internal web page. Author: John P. Riehl. Adapted from: VARITOP User's Guide, JPL

4. User's Guide To MIDAS, Draft, JPL, 1991.

5. System Analysis Branch web page: http://trajectory.grc.nasa.gov/tools/midas.shtml, June 2004.

6. Melissa L. McGuire, Stanley K. Borowski, Lee M. Mason, and James Gilland, High Power MPD Nuclear Electric Propulsion (NEP) for Artificial Gravity HOPE Missions to Callisto, STAIF, February 2003. 
Public reporting burden for this collection of information is estimated to average 1 hour per response, including the time for reviewing instructions, searching existing data sources, gathering and maintaining the data needed, and completing and reviewing the collection of information. Send comments regarding this burden estimate or any other aspect of this collection of information, including suggestions for reducing this burden, to Washington Headquarters Services, Directorate for Information Operations and Reports, 1215 Jefferson Davis Highway, Suite 1204, Arlington, VA 22202-4302, and to the Office of Management and Budget, Paperwork Reduction Project (0704-0188), Washington, DC 20503.

\begin{tabular}{|l|l|l}
\hline 1. AGENCY USE ONLY (Leave blank) & $\begin{array}{c}\text { 2. REPORT DATE } \\
\text { August } 2004\end{array}$ & $\begin{array}{c}\text { 3. REPORT TYPE AND DATES COVERED } \\
\text { Technical Memorandum }\end{array}$ \\
\hline
\end{tabular}

4. TITLE AND SUBTITLE

5. FUNDING NUMBERS

Nuclear Electric Propulsion Application: RASC Mission Robotic Exploration of Venus

6. AUTHOR(S)

Melissa L. McGuire, Stanley K. Borowski, and Thomas W. Packard

WBS-22-319-30-C2

\section{PERFORMING ORGANIZATION NAME(S) AND ADDRESS(ES)}

National Aeronautics and Space Administration

John H. Glenn Research Center at Lewis Field

Cleveland, Ohio 44135-3191

8. PERFORMING ORGANIZATION

REPORT NUMBER

E-14732

\section{SPONSORING/MONITORING AGENCY NAME(S) AND ADDRESS(ES)}

National Aeronautics and Space Administration

Washington, DC 20546-0001
10. SPONSORING/MONITORING AGENCY REPORT NUMBER

NASA TM-2004-213225

AIAA-2004-3981

\section{SUPPLEMENTARY NOTES}

Prepared for the 40th Joint Propulsion Conference and Exhibit cosponsored by the AIAA, ASME, SAE, and ASEE, Fort Lauderdale, Florida, July 11-14, 2004. Melissa L. McGuire and Stanley K. Borowski, NASA Glenn Research Center; and Thomas W. Packard, Analex Corporation, 3001 Aerospace Parkway, Brook Park, Ohio 44142. Responsible person, Melissa L. McGuire, organization code 7820, 216-977-7128.

12a. DISTRIBUTION/AVAILABILITY STATEMENT 12b. DISTRIBUTION CODE

Unclassified - Unlimited

Subject Category: 13

Distribution: Nonstandard

Available electronically at http://gltrs.grc.nasa.gov

This publication is available from the NASA Center for AeroSpace Information, 301-621-0390.

13. ABSTRACT (Maximum 200 words)

The following paper documents the mission and systems analysis portion of a study in which Nuclear Electric

Propulsion (NEP) is used as the in-space transportation system to send a series of robotic rovers and atmospheric science airplanes to Venus in the 2020 to 2030 timeframe. As part of the NASA RASC (Revolutionary Aerospace Systems Concepts) program, this mission analysis is meant to identify future technologies and their application to far reaching NASA missions. The NEP systems and mission analysis is based largely on current technology state of the art assumptions. This study looks specifically at the performance of the NEP transfer stage when sending a series of different payload package point design options to Venus orbit.

14. SUBJECT TERMS 15. NUMBER OF PAGES

Systems analysis; Venus; Nuclear electric propulsion; Transportation; Aerospace systems; NASA programs; Prometheus; Design analysis

\begin{tabular}{|c|c|}
\hline $\begin{array}{c}\text { 17. SECURITY CLASSIFICATION } \\
\text { OF REPORT } \\
\text { Unclassified }\end{array}$ & $\begin{array}{c}\text { 18. SECURITY CLASSIFICATION } \\
\text { OF THIS PAGE } \\
\text { Unclassified }\end{array}$ \\
\hline
\end{tabular}

19. SECURITY CLASSIFICATION OF ABSTRACT

Unclassified 

